\title{
Gen-Y's Aura Impact on HR New Model and Practices of Hospitality Sector
}

\author{
Jakaria Dasan*, Jennifer Chan Kim Lian, Sharija Che Sha'ari \\ Faculty of Business, Economics and Accountancy \\ Universiti Malaysia Sabah \\ jakaria@ums.edu.my*
}

\begin{abstract}
Gen-Y's employees could elicit an aura that would support the development of a sustainable HR model and practices in hospitality sector, particularly in hotel industry. Subsequently, this could revive the glaring hospitality industry which initially being portrayed through hotel. Yet, a worrying perception was unveiled that Gen-Y was reluctant to engage in a face-to-face approach, which has long become the trademark in hospitality business. This tendency might pose a challenge to the development of the aforementioned HR model and practices. Data collected from the Gen-Y cohort, and the multi-generations workforce prevail the real traits, values and work attitudes of the Gen-Y. The information would improve further the human resource practices and management. The study employed a qualitative method by conducting interviews with the three levels of staffs in the participating hotels; namely, managerial level, supervisor level, and operational level. In total, 149 respondents were interviewed. Preliminary findings found that positive support from the Baby Boomer and Gen-X will bring out Gen-Y's best aura that could position hotel industry into a driving seat of prosperous economy.
\end{abstract}

Keywords: Gen-Y; Aura: Human Resource; Hospitality; Multi-generations.

\section{INTRODUCTION}

The definition taken from Merriam-Webster refers "aura" to a special quality or feeling that seems to come from a subject whether a person, a place, or a thing. Aura would enable a particular subject becomes more obvious or noticeable, and produce an impact to its surrounding. In other words, aura provides additional strength to the subject. It is predicted to cause a significant effect to others as well. In finding the cure for her severe asthmatic eczema, Anni Sennov, the founder of Aura Transformation, created a way to treat her illness therapeutically. She managed to develop the way on how to cure her illness only in two weeks time. Bell (Dec. 2011) reported that Sennov's Aura Transformation is originated from the old aura structure which is transformed into new one. In the same report, the author pointed out Berit Reaver's, the European Director of the Aura Mediator Courses, definition of aura transformation which is like upgraded software. According to Reaver, when the latest version of an operating system is installed in a computer, information could be processed more easily, more productive and more creative. Reaver shared an analogy of how the old components of computer were responsible in the upgrading of the software into a high speed and more reliable computer. This likelihood indirectly associates the reality of the current generation known as Gen-Y, who actually rose from previous generations (parents generations; such as Generation X, and Baby Boomers). They learnt about the older generational traits, and could add the way they perceive them. This is how aura impact of Gen-Y develops.

In the current study, the objective is to explore whether Gen-Y's aura could provide an impact to the development of new HR models and practices. Focus is given more to Gen-Y since they are not only the largest workforce to be, but also knowing the fact that future potential customers would be predominantly from this cohort of generation as well. Gen-Y has been foreseen to better fulfilled the expectation of growing numbers of customers. On this note, changes are required to successfully recruit, select, train and motivate those from Gen-Y in achieving the organizational goal. Thus, efforts to adapt Gen-Y's unique traits, values and work relationship with HR new models and practices should be well embedded. Noteworthy, due to Gen-Y's technology savvy, me oriented, slowness and other passive-sound traits (Zopiatis et. al., 2011), an irritating perception was built up. Gen-Y managers had been found to be slower in face-to-face approach when dealing with customers (Martin, 
2005). This tendency contradicts the existing routine in customer service orientation in the hotel industry in which hotel's service has been highly associated to greater hospitality practice, whereby direct and indirect employee-customer interactions are mesmerized (Solent \& Hood, 2008; Berry, 1995).

\subsection{General Overview of Hospitality Sector}

As one of the most important players of tourism industry that is banking on hospitality service, plenty face-to-face nature of dyad relationship between customers and employees becomes a common scenario (Adam, 1976). Despite of the challenges that led to the downturn of tourism sector, there is no compromise on the way hospitality being practiced. The growing inclusion of more Gen-Y employees into hotel industry should be nurtured with this workplace culture. Furthermore, it was mentioned that more tourists or customers coming from this generation as well. Hence, Gen-Y should be having more advantage in giving a much needed assistance. Yet, as it was mentioned in previous paragraph, Gen-Y possesses some attitudes that reversely match the hospitality expectation. Nevertheless, such worrying traits and characteristics could merely be a direct translation of the characteristics of the generation itself as seen by people of other generations. Put it differently, this might arise from a perceptual gap that has generalized this cohort as having such remote attitudes (Martin, 2005). Martin (2005) had further reiterated his allegation which was solely based on the anecdotal evidence. Wikipedia source describes anecdotal evidence as a dubious support of a generalized claim. It is no more than a type description which often "being confused in discussions with its weight, or other considerations, as to the purpose for which it is used regardless of the veracity of individual claims." In short, anecdotal evidence is not justified since it is not scientifically proved.

Hence, as proposed earlier, some genuine characteristics of Gen-Y's employees could be fairly unveiled that they could elicit elements generating aura impact. Subsequently, this could be adapted to formulate the new HR models and practices. In proposing this idea, a qualitative study was undertaken involving 149 hotel employees in Kota Kinabalu and Sandakan, in the state of Sabah. The research question guiding this study is to what extend does Gen-Y traits, values and work attitude produce an aura impact that will strengthen the new HR models and practices. Prior to the justification of the research findings, the researchers had reviewed literatures on related issues.

\section{LiTERATURE REVIEW}

In general, scholars (such as Zopiatis, Kapardis, Varnavas, \& Pavlou, 2011; Rood, 2010; Hole, Zhong, \& Schwartz, 2010; Nicholas, 2009; Lim \& Wong, 2009; Down, Ho \& Locke, 2008; Dries et. al., 2008; Gursoy, Maier \& Chi, 2008; Zemke, Raines \& Filipczak, 2000) had identified four cohorts of generations. Among the names given to these cohorts are Traditionalists or Matures, Baby Boomers, Gen-X or Nexters, and Generation Y or Millennials. Each generation is represented with different years of birth. Even though the years of birth were not duplicated to one another due to the different context of study, research had revealed that all generations have a time span of 20 to 25 years in between them (Eyerman \& Turner,1983). Hence, for Traditionalist or Matures, their years of birth should be around early 1940s and before. Baby Boomers were born before early 1960s, Gen-X or Nexters early 1980s, and Gen-Y or Millennials by the end of 1990s and before. Those scholars commonly agreed that people in similar cohort share similar life experiences which were influential in the development of their personality. Currently, only three generations are considered as having influence at the workplace; namely Baby Boomers, Gen-X and Gen-Y. These three generations compose the current workforce. Due to age factor, the Tradionalists have been leaving the workplace. Noteworthy, in the Malaysia's context, Boomers, Gen-X, and Gen-Y are born from 1946 to1964, 1965 to1979, and 1980 to 1995 respectively (Lim \& Wong, 2009). Various authors had provided general descriptions of the characteristics for each generation of employees (Dries, et al., 2008; Gursoy, Maier, \& Chi, 2008; Zemke, Raines, \& Filipczak, 2000).

\subsection{Generational Theory}

Theories on generation were mostly espoused from the definition of generation itself. Among the early definitions of generation were by Marias (1970), "generation as people who have experienced similar environmental conditions, such as political events, economics situations and technological changes, will have related outlooks," Mannheim (1972), "a group of people of the same age in a similar social location experiencing similar social event," and Kupperschmidt (2000), " a generation 
as an identifiable groups, which shares years of birth and hence significant life event at critical stages of development." In another literature (Solent \& Hood, 2008), Kupperschmidt's definition of generation was further extended to an identifiable group of generation that could be divided into two groups; namely the first wave or core group, and the last wave. There is a meagre difference in attitudes and views between them.

Notwithstanding, in the context of workplace, scholars defined generation as representing a group of people who have common traits, values and work relationship (Eyerman \& Turner, 1983). Eyerman and Turner (1983) defined generation as people who pass through time and share a common habitus, hexis and culture, a function of which to provide them with a collective memory that serves to integrate the generation over a finite period of time. This definition was used as the guiding theory in pursuing the current research. Generally, this definition and those by others, had been derived after solving various arguments. For example, a research by Arsenault (2004) noted that people erroneously believed that the generational differences in the forms of values, attitudes and preferences were solely due to age factor. As people grow older, people assimilate into different generation. McGuire and colleagues (2007) added to this argument that the traits resist change caused by social and cultural advances. In relation to such arguments, Wong and colleagues (2008) claimed the stereotyping of generation was not correct. Nevertheless, those arguments have greatly affected the establishment of a standard definition to generation that can act as a guiding theory on research involving multigenerational gap. Common understanding on the definition of generation has generated the identification of generational characteristics which were shown in Table 1. Those characteristics were viewed in terms of how individual perceive the eight issues.

Table1. Generational Perspectives on Relevant Issues

\begin{tabular}{|c|c|c|c|c|}
\hline Issues & Traditionalist/Matures & Baby Boomers & Gen-X/Nexters & Gen-Y/Millennials \\
\hline Outlook & Practical & Optimistic & Skeptical & Hopeful \\
\hline Work Ethic & Dedicated & Driven & Balanced & Ambitious \\
\hline View of Authority & Respectful & Love/hate & Unimpressed & Relaxed, polite \\
\hline Leadership by... & Hierarchy & Consensus & Competence & $\begin{array}{c}\text { Achievement, } \\
\text { pulling together }\end{array}$ \\
\hline Relationships & Self-sacrifice & Personal gratification & Reluctance to commit & Loyal, inclusive \\
\hline Perspective & Civic-minded & Team-oriented & Self-reliant & Civic-minded \\
\hline Turn-Offs & Vulgarity & Political incorrectness & Clichés, hype & $\begin{array}{c}\text { Cynicism, } \\
\text { condescension }\end{array}$ \\
\hline
\end{tabular}

Source: Raines \& Ewing (2006)

\subsection{Generation $Y$ and other Generations}

The current study specifically focuses on Gen-Y because this generation will be the group of generation that need to be attracted, recruited and retained in the workforce to meet the expanding tourism industries which saw new hotel ventures and projects coming up. Downe, Ho, \& Loke (2008), who did a study on the retention and engagement level of Malaysian workforce, noted that Gen-Y has different attitudes, different motivations, and different ways of behaving at work. Gen-Y has created an atmosphere where loyalty is more towards lifestyle rather than the job (Rorholm, 2007; Solomon, 2008). Gen-Y expects career advancement or promotions to be much faster. Work attitudes have changed due to Gen-Y's technological adeptness. They are capable at completing works earlier based on "9 to 3 schedule" rather than the traditional, "9 to 5" (Rorholm, 2007; Solomon, 2008). Individuals of Gen-Y are also addicted to change. They require on-going training, expect consistent feedback, and need to be rewarded immediately for accomplished jobs. Gen-Yers believe in collective action that for them, "the more the merrier" (Gursoy, et al., 2008). Thus, they favour teamwork and easily engage in collaborative activities. They are not afraid in telling their bosses or superiors the way things should be handled for better outcomes. Moreover, Gen-Yers may have better opportunity and perseverance at work due to their closeness with technology adeptness (Gursoy, et al., 2008; Zemke, et al., 2000). Technology adeptness enables them to gain more advantage in seeking more information or knowledge that could benefit service-oriented industry.

As for comparison, Gen-X workers are highly creative, productive and independent. They manage to complete a given task without needing much supervision. Nonetheless, they pay a particular attention on career growth, and personal acknowledgement, but not on bigger salary. They value change as long as it does not affect their life satisfaction. In view of this, they put much concern on working 
hours. Any change in working hours could affect the work life balances that they have been vocal of. Meanwhile Baby Boomers are not as many as Gen-X. Recent development had shown this generation had lengthened their service due to the age increase in the retirement plan. The immediate impact shows the inability of younger generations to be promoted on the upper hierarchy in an organization. Due to the delayed retirements, slow job growth, and increasing life expectancy, normal succession planning in the organization's human resource planning was marred. Even though, Baby Boomers will eventually retire at the end of the day, it does cause further perceptual gap which being felt more by Gen-Y.

\section{Methodology}

From the month of January to November, 2015, a team of researchers from Faculty of Business, Economics and Accountancy, University Malaysia Sabah, had interviewed 149 employees of 5-star, 4-star, and 3-star business hotels around Kota Kinabalu and Sandakan. The employees were from three levels of operations; namely, managerial, supervisorial, and operational. The assistances received from the participating hotels were great. An average of four hours was spent in conducting the interview which separated the three different levels of employees. The findings were administered using 3-step methods. The first step is based on note transcribing using a tape recorder. The second step is based on notes taken during the interview by the research assistance accompanying the interviewer. The third step is based on discussions held among the researchers to reach the findings. At the end, results were drawn. In order to suit the purpose of the current study, the findings concentrate on identifying the particular traits or characteristics of Gen-Y that could be distinguished as contributing to Gen-Y's aura impact.

\section{Findings \& Discussions}

The following notes represent some of the importance findings that can be generalized into two major areas; team capacity and individual capacity which highlight Gen-Y's aura impact;

\subsection{Team Capacity}

In its effort to incite employees' citizenship, a hotel forms a team consisting of the above par performance employees to motivate other employees. The team is called 'Customer Delight Team.' Basically, the team comprises of permanent staffs who act as mentor to other employees. The team has its own get-together gathering schedule where they engage in informal discussion on how to further improve their performance that will further elevate the hotel achievement. Gen-Y employees contribute a more creative approach in this team. For instance, a Gen-Y staff would request shift replacement by working on his off-day just to entertain tourists' request. The reason given by the employee is related to the current drop of tourism industry in which hotel should fill the tourist need based on their availability and that tolerate approval should be given to the employee.

Another hotel introduced 'Customer Driving Preference' group in which highly performed employees were grouped together and meet regularly to discuss the best practices that tourists enjoyed. Due to Gen-Y's practicality in technology, they have wider knowledge and can share fast information with the tourists. As a result, they always come up with interesting information to share with in the Customer Driving Preference group.

In line with the social age era, staffs of this generation are able to communicate faster using the gadgets and internet. This capability enables them to be first in receiving instruction or idea, as well as giving feedback instantly. Hotel is an integrated workplace whereby all departments need to operate simultaneously in performing a service to customer. Hence, Gen-Y does not have the problem in fulfilling this expectation.

\subsection{Individual Capacity}

For a crowded hotel, it is not easy to get staffs to entertain customers. However, Managers found that the Gen-Y employees were more willing to offer help in attending customers' requests. Another instance reveals that Gen-Y's staffs like personal attention. Thus, when the managers ask for their assistance, they took it as personal preference.

Gen-Y techno savvy, for example, in using social media enables them to become the members of global community. They enjoy spending time with foreign tourists as they get the 'practical' experience of sharing and learn more things from the tourists practically. Their eagerness in attending 
tourists should be made as a habit to all employees across generations. Thus, the Gen-Y's staffs could share their experiences.

The trend show that more and more tourists are from Gen-Y. This seems to best explain why adopting the Gen-Y's aura impact into new HR system is crucial. Moreover, tourists found it more convenient encountering younger hotel staffs.

\section{CONClusion}

Inculcating Gen-Y's aura impact, which can be translated as their teamwork and individual capacities, into the new HR models and practices could be the best approach in reviving back the gloomy tourism industry in Malaysia, particularly in the State of Sabah. Year 2015, was indeed a challenging year for the tourism industry in Sabah, following a number of unfortunate incidents befalling the State of Sabah. The incidents have greatly affected the number of tourist arrivals. Consequently, this hurt the State tourism development sector in general. As reported by the Chief Minister of Sabah when tabling the 2016 Budget of the State of Sabah, "...during the first seven months of the year 2015, the recorded number of tourist arrivals was 1,840,447, a reduction of $2.6 \%$ from $1,889,301$ visitors in the same period last year. From that total, domestic tourist arrivals recorded a decrease of $1.3 \%$ while foreign visitor's arrival indicated a decrease of 5.4\%" (Musa Aman, Nov. 2015). In response to these challenges, tourism sector received a big boost. Other than receiving bigger development allocation of Ringgit Malaysia 103 billion, some new strategies would be implemented to pace up tourism industry again. Nevertheless, the bottom line is to ensure that hotel industry could always maintain its presentable workforce. In this case, there is a need to enhance the capability of hotel employees as well. This is because hotel industry is strongly linked to hospitality service. Moreover, investigating what the latest workforce of Gen-Y could contribute to is timely since there is a growing trend of youth travellers around the global. Their distinct aura may transform not only the HR system but also a new concept of hospitality approaches as well.

\section{ACKNOWLEDGEMENT}

The study is part of the research endeavours sponsored under Malaysian Ministry of Education Fundamental Research Grant Scheme entitled "Developing and Managing Sustainable Tourism Human Resource: New HR Model and Practises." This on-going project is led by Prof. Dr Jennifer Chan Kim Lian, Faculty of Business, Economics \& Accountancy, University Malaysia Sabah. The team members are Sharija Che Sha'ari and Jakaria Dasan (the main and corresponding author). The grant registration number is FRGS0374-SS-1/2014.

\section{REFERENCES}

[1] Bell, T. Dec. (2011). Aura transformation. Kindret Spirit. Retrieved from http://auratrans formation.com/tag/download-pdf/

[2] Zopiatis, A., Kapardis, M. K., Varnavas, A., \& Pavlou, I. (2011). Generational differences in the hospitality industry: An issue of concern? International CHRIE Conference- Refereed Track. Paper 4. Retrieved from http:// scholarworks.umass.edu/refereed/ICHRIE_2011/ Thursday/4.

[3] Martin, C. (2005). From high maintenance to high productivity: what managers need to know about Generation Y. Industrial and commercial training, 37(1), 39-44.

[4] Solent, D., \& Hood, A. (2008). Generation-Y as Hospitality Employees: Framing a Research Agenda. Journal of Hospitality and Tourism Management, 15, 59-68. http://dx.doi.org/10.1375/jhtm.15.59

[5] Berry, L. (1995). On great service: A framework for action. New York: Free Press

[6] Adam, (1976). The structure and dynamics of behaviour in organizational boundary roles. In Handbook of Industrial and Organizational Psychological, ed. M. Dunnette, 1175-1199. Chicago: Rand McNally.

[7] Rood, A. S. (2010). Understanding generational diversity in the workplace: What resorts can and are doing. Journal of Tourism Insights. 1(1), 80-89.

[8] Hole, D., Zhong, L., \& Schwartz, J. (2010). Talking about whose generation? Why Western generational models can't account for a global workforce. Deloitte Review, 6, 84-97.

[9] Nicholas, A. J. (2009). Generational perceptions: Workers and consumers. Journal of Business and Economics Research. 7(10). 47-52. 
[10] Downe, A. G., Ho, J. S. Y., \& Loke, S. P. (2008). The agenda for the new service workforce. A Manpower Malaysia White Paper: Manpower Inc.

[11] Dries, N., Pepermans, R., \& De Kerpel, E. (2008). Exploring four generations' beliefs about career: Is "satisfied" the new "successful"? Journal of Managerial Psychology, 23(8), 907-928.

[12] Gursoy, D., Maier, T. A., \& Chi, C. G. (2008). Generational differences: An examination of work values and generational gaps in the hospitality workforce. International Journal of Hosp. Management, 27, 448-458.

[13] Zemke, R., Raines, C., \& Filipczak, B. (2000). Generations at work: Managing the clash of Veterans, Boomers, Xers and Nexters in your workplace (2nd ed.). NY: American Management Association.

[14] Eyerman, R., \& Turner, B. S. (1998). Outline of a theory of generations. European Journal of Social Theory, 1(1), 91-106.

[15] Lim, C. H., \& Wong, M. (2009). Malaysia's Gen Y unplugged. Pricewaterhouse Coopers Survey on Millennials at Work. Retrieved from In H. R. Advisory (Ed.): PricewaterhouseCoopers Advisory Services Sdn Bhd.

[16] Marias, Julian (1970), Generations: A Historical Method, University, AL: University of Alabama Press.

[17] Mannheim, K. (1952). Essays in the Sociology of Knowledge, ed. and trans. P. Kecskemeti. . London: Routledge \& Kegan Paul.

[18] Kupperschmidt, B. (2000). Multigenerational employees: strategies for effective management. Health Care Manage, 19(1), 65-76.

[19] Arsenault, P. (2004). Validating generational differences: A legitimate diversity and leadership issue. The Leadership \& Organization Development Journal, 25(2): 121-141.

[20] McGuire, D. By, R.. \& Hutchings, K. (2007). Towards a model of human resource solutions for achieving intergenerational interaction in organizations. Journal of European Industrial Training, 31(8): 592-608.

[21] Wong, M., Gardiner, Lang, W., \& Coulon, L. (2008). Generational differences in personality and motivation: Do they exist and what are the implications for the workplace? Journal of Managerial psychology, 23(8): 878-890.

[22] Raines, C. \& Ewing, L. (2006). The art of connecting: How to overcome differences, build rapport, and communicate effectively with anyone. New York: AMACON

[23] Rorholm, J. (2007). Generational gap changes roles for employees. Knight Ridder Tribune Business News. Retrieved from http: //www. redfusionmedia. com/ arc_managing generation_Y_millennials. htm

[24] Solomon, R. (2008). Running a Business: Learning to Manage Millennials. Online edition. Wall Street Journal (Eastern edition).

[25] Musa Aman, (Nov., 2015). The 2016 Budget Speech. The State Legislative Assembly. Retrieved from https:// www.sabah.gov.my /main /Content/budget/State/2016StateBudgetSpeech.pdf. 


\section{AUTHORS' BIOGRAPHY}

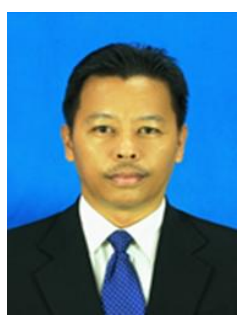

Jakaria Dasan, is the main author and correspondence author of this article. He is a faculty member at Faculty of Business, Economics \& Accountancy at Universiti Malaysia Sabah. His main research interest concerns Human Resource Management. He teaches Corporate Communication for Undergraduate Program and Management and Organizational Behavior for Postgraduate Program. He had pursued his BSc. in Public Administration in West Texas A\&M University, U.S.A., and Master of Business Administration from Universiti Malaysia Sabah. He had more than 15-year experiences as Human Resource Personnel before becoming faculty member in 2010.jackarea69@gmail.com

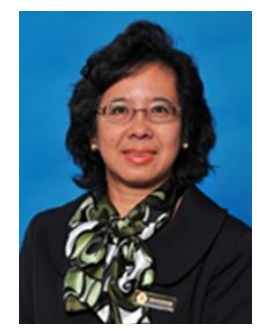

Professor Dr. Jennifer Kim Lian Chan, holds a $\mathrm{PhD}$ degree in Tourism and Hospitality Management and is a tourism lecturer at the Faculty of Business, Economics and Accountancy, Universiti Malaysia Sabah. She has the expertise in fields related to tourism and hospitality which areas include sustainable tourism, hospitality human resource development, tourism consumer behaviour and service experience management, qualitative and mixed methods in tourism and hospitality management research. Currently, she serves as a national panel auditor for the Tourism and Hospitality Program Accreditation; committee member of the Entry Point Project (EPP10)- Tourism and Hospitality Cluster and the Malaysian Centre for Tourism and Education (MyCenThe). Her research works have been published in high impact tourism and hospitality journals and received several awards. jkimchan@yahoo.co.uk

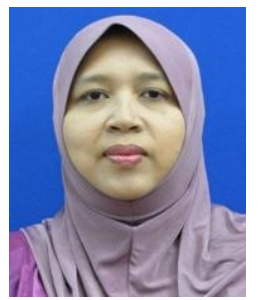

Madam Sharija Che Shaari, is a senior lecturer at Faculty of Business, Economics and Accountancy, Universiti Malaysia Sabah. She completed her LL.M in International Business and Company Law from East Anglia University, United Kingdom. Her expertise is in law, particularly on international business and company law.Sharija@ums.edu.my 